\title{
Municipal demarcation process in the establishment of the Collins Chabane Local Municipality and reasons for the eruption of Vuwani, South Africa
}

\begin{tabular}{|c|c|}
\hline \multicolumn{2}{|c|}{$\begin{array}{l}\text { Authors: } \\
\text { Mavis M. Netswera }{ }^{1} \text { (1) } \\
\text { Eric J. Nealer }{ }^{1}\end{array}$} \\
\hline \multicolumn{2}{|c|}{$\begin{array}{l}\text { Affiliations: } \\
{ }^{1} \text { Department of Public } \\
\text { Administration and } \\
\text { Management, School for } \\
\text { Public and Operations } \\
\text { Management, Faculty of } \\
\text { Economic and Management } \\
\text { Sciences, University of } \\
\text { South Africa, Pretoria, } \\
\text { South Africa }\end{array}$} \\
\hline \multicolumn{2}{|c|}{$\begin{array}{l}\text { Corresponding author: } \\
\text { Eric Nealer, } \\
\text { nealeej1@unisa.ac.za }\end{array}$} \\
\hline \multicolumn{2}{|c|}{$\begin{array}{l}\text { Dates: } \\
\text { Received: } 14 \text { Feb. } 2019 \\
\text { Accepted: } 07 \text { Nov. } 2019 \\
\text { Published: } 23 \text { Apr. } 2020\end{array}$} \\
\hline \multicolumn{2}{|c|}{$\begin{array}{l}\text { How to cite this article: } \\
\text { Netswera, M.M. \& Nealer, E.J., } \\
2020 \text {, 'Municipal demarcation } \\
\text { process in the establishment } \\
\text { of the Collins Chabane Local } \\
\text { Municipality and reasons for } \\
\text { the eruption of Vuwani, } \\
\text { South Africa', The Journal for } \\
\text { Transdisciplinary Research in } \\
\text { Southern Africa 16(1), a674. } \\
\text { https://doi.org/10.4102/ } \\
\text { td.v16i1.674 }\end{array}$} \\
\hline \multicolumn{2}{|c|}{$\begin{array}{l}\text { Copyright: } \\
\text { (c) 2020. The Authors. } \\
\text { Licensee: AOSIS. This } \\
\text { is licensed under the } \\
\text { Creative Commons } \\
\text { Attribution License. }\end{array}$} \\
\hline \multicolumn{2}{|l|}{ Read online: } \\
\hline 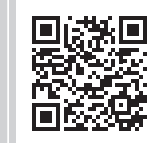 & $\begin{array}{l}\text { Scan this QR } \\
\text { code with your } \\
\text { smart phone or } \\
\text { mobile device } \\
\text { to read online. }\end{array}$ \\
\hline
\end{tabular}

\begin{abstract}
The demarcation of municipal boundaries in post-apartheid South Africa is characterised by objections from affected communities. Beyond polarising-affected communities, proposed redeterminations regularly elicit destruction of public infrastructure and even loss of life. Hostilities over municipal boundaries which were drawn in the rural areas for the first time. This article is drawn from the highly publicised demarcation unrests experienced in the Vuwani area as a result of the newly established Collins Chabane Local Municipality in the Limpopo province. Findings reflected in this article emanated from data collected through the questionnaire, interviews and secondary data sources. Empirical evidence uncovers low levels of public participation in demarcation process by the residents. Actually, more people in Vuwani participated in the anti-demarcation protests in objection to the new municipality. The fact that violent protests regularly accompany municipal demarcation objections in South Africa could reflect an urgent need to improve the facilitation of meaningful public participation in the municipal demarcation process.

Keywords: Collins Chabane Local Municipality; Vuwani; Malamulele; local government; demarcation process; protests; public participation challenges.
\end{abstract}

\section{Introduction}

This article ascertains if local experiences confirm the assertions of scholarly literature in relation to the notion of participatory governance, specifically if community members in the Collins Chabane Local Municipality (CCLM), who were directly affected by municipal redeterminations, participated actively in this process and how the Municipal Demarcation Board (MDB) brought them on board. Municipal boundaries in South Africa are reviewed every 5 years in anticipation of the municipal electoral period. Considerations like bringing together areas with functional linkages, assigning enough voters to various geographic areas, promotion of sharing of resources and the delivery of services, and municipal financial sustainability could all necessitate these adjustments (Matemba 2000:2; Napier 2007:180). These boundary adjustments range from minor technical alignments of the boundaries between municipalities to major changes, which could include amalgamation of some municipalities and the establishment of new municipal jurisdictions (Mahlangu 2011:Internet).

It has become common for communities affected by municipal redemarcations to object these state-led demarcation efforts. These objections are often accompanied by violent protests from affected communities across the country. Numerous disapprovals emerged during the first postapartheid municipal demarcations in preparation for the first non-racial local government elections in 1995. Similar redemarcation objections that were mostly accompanied by violent protests ensured in areas such as Khutsong, Matatiele, Moutse, Zamdela and Malamulele, to name but a few. One of the key drivers of violent protests relates to the government's failure to involve communities in the demarcation decision that directly affects them. Residents' objections to redemarcation proposals include a lack of transparency in the demarcation process and poor communication between the government, the MDB and communities (Hornby 2004:27; Matemba 2000:4; Mavungu 2012:60-62; Mokgosi 2013:Internet; Municipal IQ 2013:1). For instance, the proposed merger of Metsimaholo with Ngwathe local municipalities in the Free State province in 2013 witnessed the residents of Zamdela community go on a rampage. The residents believed 
at the time that the neighbouring Ngwathe was poorer, suffered from maladministration and would benefit from their municipal resources without contributing anything whatsoever. Four lives were alleged to have been lost during these protest activities. It subsequently emerged that these protests might have been prevented if the residents had been adequately consulted about the proposed merger. Thankfully, the MDB did not go ahead with the proposed merger (Mokgosi 2013:Internet; Municipal IQ 2013:1-2).

At the beginning of 2015, the Minister of the National Department of Cooperative Governance and Traditional Affairs (COGTA) requested the MDB in terms of Section 22(2) of the Local Government: Municipal Demarcation Act 27 of 1998 (hereafter referred to as the Demarcation Act) (Republic of South Africa [RSA] 1998) to reopen the determination of outer boundaries of specific municipalities to optimise the financial viability. This request came about 2 years after the finalisation of the redemarcation process for the 2016 local government elections. In addition, the request was a major departure from the usual criteria for local government demarcations because municipal financial viability, amongst other factors, was placed at the core of boundary changes (COGTA 2015:25; Khumalo \& Ncube 2016:1). The question that has risen out of this proposal was whether financial viability should be the key driver of these redeterminations. What appears to be a gap in the Demarcation Act is its silence on how the MDB should go about ensuring that all of the demarcation factors are indeed complied with. Failure to apply all factors correctly may create municipalities that are unable to fulfil their constitutional mandate (Bekink 2006:220; Khumalo \& Ncube 2016:1; Mzakwe 2016:1-2).

Accordingly, the MDB proceeded with the redetermination of 19 local municipalities in seven provinces, including the new local municipality (now named the CCLM in the Limpopo province [16 on Figure 1]).

In this case, the minister requested the MDB to redetermine the municipal boundaries of Thulamela, Makhado and Musina local municipalities by disestablishing the Mutale Local Municipality (LM) in the Vhembe District Municipality (DM). The aim was to optimise the financial viability of all the municipalities in the district. Furthermore, this proposal formed part of the 'Back to Basics' policy agenda for local government, which is a plan of action to ensure that municipalities realise their constitutional mandate by putting people first, ensuring delivery of basic services, good governance and sound financial management whilst building strong institutions (Municipal Demarcation Board [MDB] 2015a:1, 11).

Instead of redetermining the municipal boundaries of the Vhembe DM as requested by the minister, the MDB decided to disestablish the Mutale LM and to establish a new municipality comprising portions of the municipal areas of Makhado and Thulamela, that is, Vuwani and Malamulele, respectively (MDB 2015a:1-2). This decision was indeed a victory to the XiTsonga people of Malamulele, who had been demanding a separate municipality from the Thulamela LM through violent demonstrations since 2000. Fuelling the demand was the claim that the TshiVenda-dominated Thulamela LM was channelling services to TshiVendaspeaking areas (especially Thohoyandou where the municipal council seats) to the detriment of the Malamulele community. Unlikely, a feasibility study conducted by the MDB found that the area did not meet all the demarcation criteria (MDB 2015b:9,18; Rasila \& Musitha 2017:4).

The reminder of the article is structured as follows: firstly, the methodology is presented, followed by the theoretical basis on which public participation in the municipal demarcation is based, the legal process of determining and redetermining municipal boundaries and the research findings. Then the discussion is presented and finally the article concludes with a conclusion and the way forward.

\section{Methodology}

This article adopted a mixed-method approach consisting of a questionnaire, personal interviews, focus group discussion and document analysis. Purposeful sampling facilitated the selection of two municipal officials - one from the CCLM and the other from the Vhembe DM - who were subjected to semi-structured interviews. Systematic random sampling involved the selection of representatives of 100 households from 10 villages in the CCLM for questionnaire administration. Five villages belonged to Malamulele area and another five were selected from Vuwani area. There was an even spread in the number of participants, with an average of five per village. While $15 \%$ and $11 \%$ of the participants were from Hatshikonelo and Hamashau-Mukhoro respectively, approximately $60 \%$ came from the villages of Hamasia (10\%), Ramukhuba (10\%), Tshino (10\%), Basani $(10 \%)$, Tshigalo $(10 \%)$ and Malamulele (10\%). The remainder spreads out as follows: Hamashau-Misebe B (9\%) and Mukhoni (5\%). A focus group discussion took place with five MDB officials who are knowledgeable about and responsible for delimitations and determinations of the municipalities in South Africa. Secondary data analysis came from municipal official documents, reports of the legal proceedings involving court cases by residents who opposed the MDB's decision to incorporate their area into new local municipality and formal investigation reports that were requested and obtained from the MDB.

\section{Local democratic participatory perspective}

It is widely accepted that local government provides a platform for citizens to involve themselves in local decisions that affect their lives. This viewpoint has been corroborated by different authors who assert that local government exists to promote local democracy, which is a political system based on representative government, citizen participation in the political process, basic freedoms of citizens and transparency of political processes in general (Eremenko 2014:Internet; Finn 2008:13-14; Pillay, Reddy \& Sayeed 2015:46-48). The 
history of this view dates back to philosopher Jean Jacques Rousseau, who laid the foundation for theories on participatory democracy by insisting that the participation of each citizen in political decision-making is vital to the functioning of the state (Michels \& De Graaf 2010:479).

Concurring with the perspective that local government exists in order to allow the local populace to actively participate in affairs directly affecting them, Reddy (1999:13) goes on to list the functions of local government as:

- involving citizens in the performance of local public duties

- strengthening the restrictions and controls of political power, which are indispensable to a democracy

- widening the basis of political participation

- safeguarding pluralism at various levels and different local administrative units

- facilitating problem-oriented grassroots approaches which citizens appreciate.

Public participation is also regarded as a contributor to citizens' feeling of being public citizens. Through their involvement in the political process, citizens feel that they are part of their communities and more personally responsible for public decisions (Michels \& De Graaf 2010:480). When people participate in government affairs, Sikander (2015:175) adds that government powers do not remain concentrated at the centre but are obviously shared by the people at the local level. Moreover, citizen participation forms the basic feature of a functional and effective civil society. In this manner, civil society is viewed as a product of democracy because democracy is the system that provides all the necessary terms and conditions for civil society to prosper (Eremenko 2011:1). Other authors contend that local democracy is pivotal to a better distribution of resources, as well as to the acceleration of social and economic development in general (Scott 2004:287, 303; Sikander 2015:171). Recent research by Tommasoli (2013:13) revealed that development goals are most often achieved under two conditions: (1) where democratic institutions provide opportunities for all citizens to express their demands and to hold elected officials to account for their actions and (2) where the capacity of government is so strengthened that the state can manage the provision of public services.

Unfortunately, local government is not universally shared as an instrument that brings participatory democracy. Critics point to the relatively low level of interest in municipal politics, which manifest in voter apathy, as proof of local government unpopularity. Current evidence suggests that in many democracies, voter turnout at local government has been much lower than that at national government, and it is on the decline. The main causes of voter apathy appear to be citizens' lack of interest and trust in local government (De Visser 2009:12; Hajnal \& Lewis 2003:645-646). Another impediment associated with participatory democracy relates to local government being inundated with political interference to the extent that citizens are not consulted adequately. Central government is simply blamed for handing down laws and regulations without consulting the general populace. Desired citizen participation is further constrained by the lack of good living conditions, accountable and trustworthy leadership, vibrant community organisations and involvement of disadvantaged groups. In addition, citizen participation in developing countries has also been criticised for being about trivial issues (such as village politics) instead of being about vital issues (such as developmental priorities). Communities feel insecure and find solace in the formation of Civic Society Organisations (CSOs) in the end (Daemane 2012:208; Mapuva 2014:10-12).

The principles of participatory governance and transparency discussed in this section are at the centre of public participation in the municipal demarcation process. These principles form the basis on which the research findings are based.

\section{The legal process of determining and redetermining municipal boundaries}

The Demarcation Act provides a detailed process for the determination and redetermination of municipal boundaries in South Africa. During this process, the MDB receives a request, tests public opinion, considers the public inputs, conducts investigations and holds public meetings. This process is meant to ensure that all the different views are considered and those who are affected have the opportunity to participate.

The MDB publishes its intention to consider the proposals in newspapers circulating in the area, and any other reasonable means of communication in terms of Section 26, inviting members of the public to submit their views and representations in writing (MDB 2016:10). Public meetings may be held and formal investigation may be conducted. Following such an extensive process, the MDB proceeds to confirm, vary or withdraw its determination or redetermination, and publishes its decision in the relevant Provincial Gazette. The onus then falls on any aggrieved person to submit written objections to the MDB within 30 days (MDB 2013:35-36). Generally, the motivation behind redetermination should speak about the criteria outlined in sections 24 and 25 of the Demarcation Act. Section 24 lists demarcation objectives in line with Section 152 of the Constitution of the Republic of South Africa, 1996. The main objective when the MDB considers redetermining a municipal boundary should be to enable the municipality for that area to fulfil its constitutional obligation. Section 25 further requires careful consideration of factors such as the interdependence of people, integrated and un-fragmented areas, the financial viability and administrative capacity of the municipality, existing functional boundaries, existing land use planning and physical characteristics of the area (Republic of South Africa 1998:18).

\section{Presentation and discussion of research findings}

It became important to determine whether community members in the CCLM, and specifically Vuwani residents who rose up against the incorporation of their area into a new 
municipality, were involved in the demarcation process, and how they came to know about the MDB's intention to change boundaries. The findings are presented in five parts: participants' awareness of the MDB's existence and its responsibilities, participants' involvement in the municipal demarcation meetings and protests, public submissions in response to Section 26 notice, formal investigation in terms of Section 29 and reasons for the eruption of Vuwani.

\section{Participants' knowledge of the Municipal Demarcation Board and its responsibility}

In order to test participants' knowledge of the MDB and its role, participants were asked if they knew the MDB and its responsibilities and whether the reasons behind the MDB's decision to change the boundaries were politically motivated, in the interest of better service delivery or ethnically motivated. Astonishingly, the majority of participants in the entire municipality (91\%) did not know about the MDB. Because the majority of the participants were unaware of the MDB, it could not be established if a significant section of them understood the role of the MDB. A lack of the MDB visibility at regional and local levels is thus regarded as one of the reasons why the entity appears disconnected from the public. In its 2013 briefing on the demarcation process and challenges to the select committee on the COGTA in Parliament, the MDB emphasised the need to maintain and improve public participation in demarcation process. This includes extending the net of stakeholders much wider than just the directly affected municipalities and communities (MDB 2013:51).

\section{Participants' involvement in the municipal demarcation meetings and protests}

Table 1 reflects participants' views drawn from the questionnaire about their involvement in the demarcation process meetings as well as in the demarcation protests. The objective here was to determine whether residents affected by boundary changes were involved in the demarcation process to ensure that their views are considered.

Whilst an overwhelming majority (96\%) claimed to have never participated in any municipal demarcation meetings, there was some marginal participation of $30 \%$ in the municipal demarcation protests in Vuwani in objection to the newly proposed municipality. Furthermore, one-third (36\%) of participants confirmed that their family members had participated in the demarcation protests, and the majority were from Vuwani. With only a few exceptions, the majority of participants in both areas did not think that protesting violently was justifiable.

Significant differences $\left(\chi^{2}=0.00\right)$ were found between the respondents of Vuwani and Malamulele when it relates to their participation in the post-demarcation protests. Findings suggest that not a single participant from Malamulele protested in objection to a new municipality, whilst more than half of Vuwani participants participated in objection protests. Equally so, significant differences $\left(\chi^{2}=0.00\right)$ were also found between the respondents of Vuwani and Malamulele
TABLE 1: Participants' involvement in the municipal demarcation meetings and protests

\begin{tabular}{|c|c|c|c|}
\hline Municipal area & Yes (\%) & No (\%) & Pearson chi-square \\
\hline \multicolumn{3}{|c|}{$\begin{array}{l}\text { Have you ever participated in any municipal demarcation } \\
\text { meetings to talk about municipal boundary changes in your } \\
\text { area in the past? }\end{array}$} & 0.307 \\
\hline Malamulele & 6 & 94 & - \\
\hline Vuwani & 2 & 98 & - \\
\hline CCLM & 4 & 96 & - \\
\hline \multicolumn{3}{|c|}{$\begin{array}{l}\text { Did you participate in any municipal demarcation protests in } \\
\text { objection to a new municipality? }\end{array}$} & 0.000 \\
\hline Malamulele & 0 & 100 & - \\
\hline Vuwani & 60 & 40 & - \\
\hline CCLM & 30 & 70 & - \\
\hline \multicolumn{3}{|c|}{$\begin{array}{l}\text { Did any member of your household join in municipal } \\
\text { demarcation protests? }\end{array}$} & 0.000 \\
\hline Malamulele & 16 & 84 & - \\
\hline Vuwani & 56 & 44 & - \\
\hline CCLM & 36 & 64 & - \\
\hline \multicolumn{3}{|c|}{$\begin{array}{l}\text { Do you think violent protests are justifiable if they secure } \\
\text { authorities attention? }\end{array}$} & 0.240 \\
\hline Malamulele & 4 & 96 & - \\
\hline Vuwani & 10 & 90 & - \\
\hline CCLM & 7 & 93 & - \\
\hline
\end{tabular}

CCLM, Collins Chabane Local Municipality.

regarding the participation of their household members in the municipal demarcation protests. More than half of the Vuwani participants agreed that their household members participated in the demarcation protests, whilst more than two-thirds of the Malamuele participants were not aware of their household members' participation in the protests.

A focus group discussion with MDB officials about the question of public participation in the demarcation process in the CCLM revealed that this was a matter that was brought before the court:

'Perhaps if I could just state one thing. The question you have just raised now was the matter before the court. The high court has made a ruling. In the case of Vuwani, the matter was brought by a number of traditional leaders. I would suggest that you look at the court judgement, because it answers the questions of why it was raised by the applicants to the case saying that there was not adequate consultation and they were not part of it. They were, I think, around one thousand people who participated in the MDB's public meeting held in Vuwani.' (MDB Focus Group Discussion [three male and two female MDB officials, older than 18 years, knowledgeable about and responsible for delimitations and determinations of the country's municipalities])

The public meeting referred to in the MDB focus group discussion was held at Thohoyandou Indoor Sports Center in the Thulamela LM in April 2015. The meeting in question was about to ensure that different views are considered in the redetermination of the municipal boundaries in the entire Vhembe DM (see Figure 1, numbers 13, 14, 15 and16).

The representatives from the Vhembe DM, local municipalities, political parties, traditional leadership and the public were in attendance. Whilst all those who were able to speak were in favour of the disestablishment of the Mutale LM as it was not financially viable, the majority of them were also in favour of the establishment of the new municipality. 


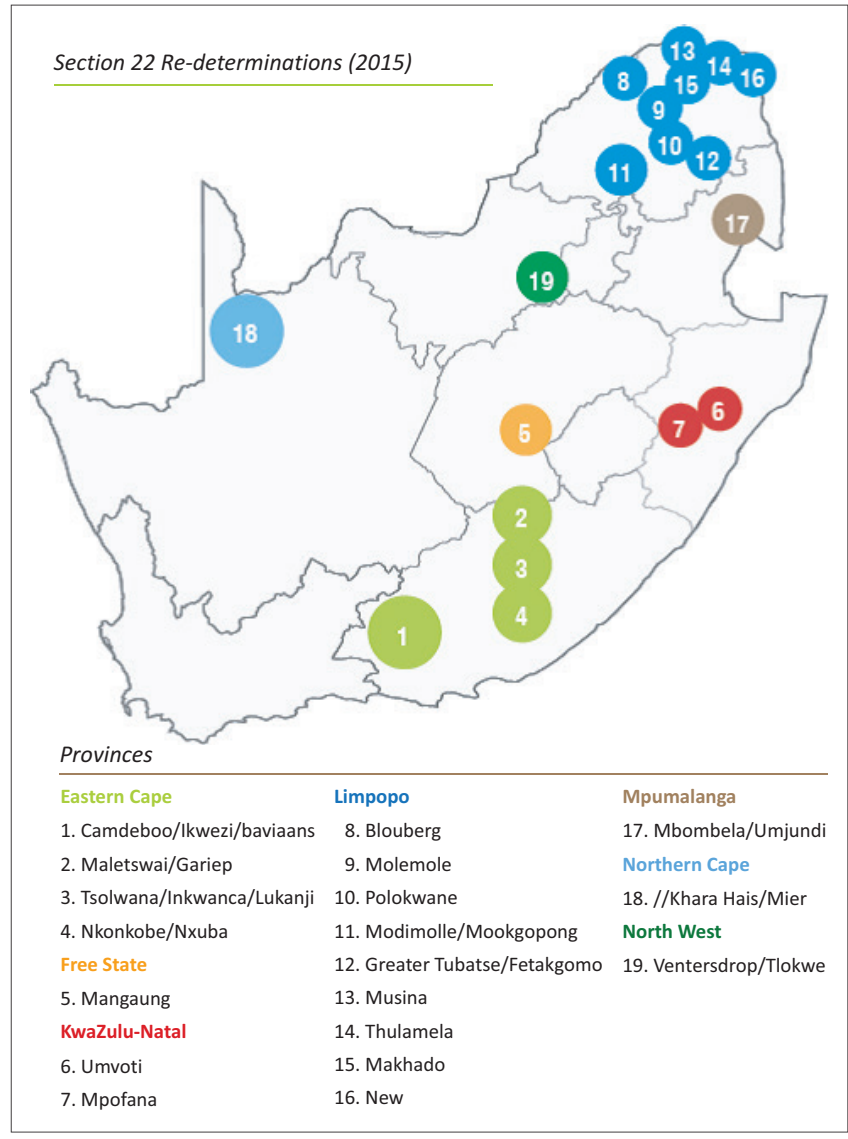

Source: Municipal Demarcation Board (MDB), 2016, Municipal Demarcation Board annual report, 2015/16: Optimising spatial planning through integration, p. 30, MDB, Pretoria.

FIGURE 1: Final reconfiguration of municipal boundaries in 2015.

The Malamulele Task Team, a structure made up of community representatives who represent the views of the residents of Malamulele, had this to say:

Malamulele people are currently not paying for municipal rates because they are not getting services from Thulamela municipality, but will not happen on a new municipality that will be providing them with services. This shows that the new municipality is a response to service delivery challenges and will help bring service delivery closer to the people and enhance social cohesion between Venda and Shangaan speaking people. There will be sustainable land development as the issue of proclamation will not be a challenge because the traditional leaders are in agreement of the new municipality. (MDB 2015a:6)

Of course, their support was not surprising, as the community of Malamulele had previously placed pressure on the MDB through violent protests action demanding their own municipality. Some representatives from communities and structural groupings such as Vuwani Demarcation Task Team also supported the establishment of the new municipality. They claimed that since 1994 the town has not been developed, there are no sewer systems in place and roads are being swept away every time it rains. The new municipality is seen as a solution to the economic and development backlog in the two areas (MDB 2015a:12-13).

Those who were opposing the establishment of the new municipality included the Tshikonelo and Masia Traditional
Councils. On the one hand, the Tshikonelo Traditional Council did not want the area to be incorporated into the new municipality, but remain under the Thulamela LM. On the other hand, Chief Masia indicated that if the new municipality was desired by the people, his community, Masia, Davhana and Tshimbupfe communities would not want to be part of it (Makgoba 2016):

Thank you Chair, I would like to thank the Chairperson. I will be short and say a few paragraphs. I am paramount Chief Masia and I speak on behalf of Masia Traditional Council. I had been sent here by Tshimbupfe Traditional Council, Nesengani, Davhana Traditional Council, Tshikonelo as well sent me and the Mulenzhe too sent me. No one is supposed to speak on our behalf. The abovementioned communities want to remain in Makhado, and the two mentioned communities who are under Thulamela to remain under Thulamela. We wrote a submission that we submitted in line with said criteria for demarcation. I will end there. There is no one in the Vuwani area who should represent us. We have not sent any person to speak on our behalf. (pp. 21-22)

In the political fraternity, some supported the disestablishment of the Mutale LM but questioned the viability of the proposed municipality. They argued that the country has been struggling with the trial and error system of municipal structures since 1995, adding that the motive underpinning the establishment of the new municipality should be about whether changes in municipal boundaries would result in functional municipalities capable of fulfilling their constitutional mandate of providing basic services to the people (MDB 2015a:12-13).

\section{Public submissions in response to Section 26 notice}

In response to a Section 26 notice (see Figure 2), the MDB received 16 submissions in total on the proposed municipality. Two of the submissions were not in support, one was not clear and the rest were in support of the new municipality (MDB 2015a:3). The following are some of the objections put forward, which the MDB received, and which urged the MDB to reconsider the incorporation of Vuwani and Malamulele to form a new municipality:

- The MDB's prescribed period of redetermination had already lapsed when the Minister of COGTA made the request for boundary changes.

- Section 25(c) of the Demarcation Act obliges the MDB to consider financial viability for a municipality to be able to perform its functions effectively and efficiently. The new municipality falls under the same category as the Mutale LM, which was disestablished because it had an $80 \%$ grant dependency. The new municipality would have grant dependency of more than $90 \%$, making it one of the most grant-dependent municipalities in the Limpopo province.

- The Thulamela LM generates most of its rates and taxes from the Thohoyandou area because of high levels of commercial and titled residential development as compared to rural communities such as Malamulele. 


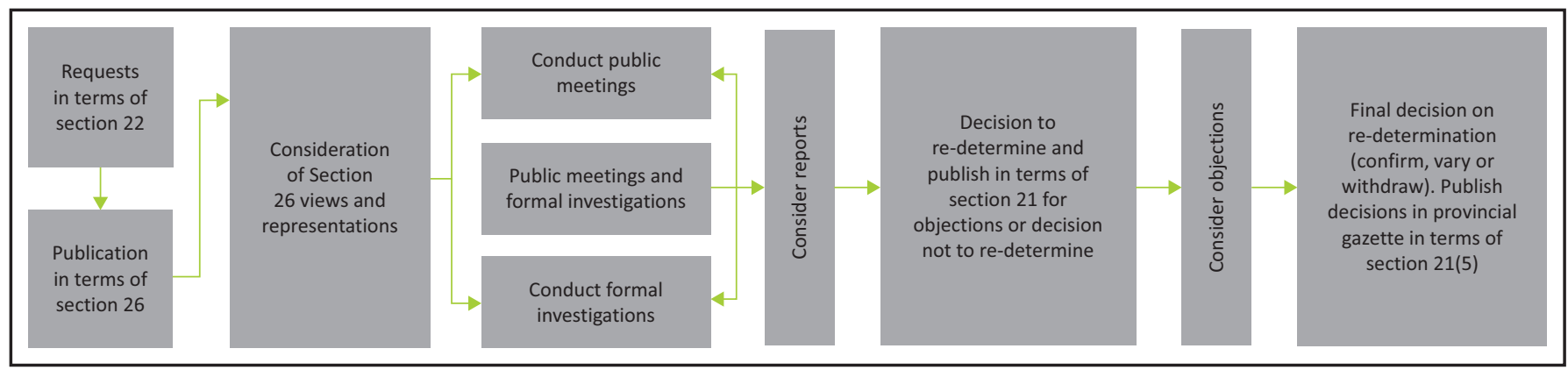

Source: Municipal Demarcation Board (MDB), 2016, Municipal Demarcation Board annual report, 2015/16: Optimising spatial planning through integration, p. 18, MDB, Pretoria. FIGURE 2: Municipal boundary redetermination process.

Therefore, the new municipality will have no tax base. This will result in the area being poorer with lack of development, high rate of unemployment and inequality.

- Funds required to establish the new municipality could be utilised to capacitate the Makhado and the Thulamela LMs and their satellite offices.

- The high concentration of the Tsonga community in the proposed new municipality area and the high number of Vendas in the remainder of the Thulamele and Makhado local municipalities will perpetuate spatial fragmentation, separate communities along ethnicity and re-introduce apartheid boundaries. This is patently against Section 25(b) of the Demarcation Act (MDB 2015a:60-66).

\section{Formal investigation: Section 29}

Because of the magnitude of the proposed boundary changes in the entire Vhembe DM, a formal investigation was conducted using an evaluation matrix tested against four categories of demarcation criterion, namely, the interdependence of people, communities and economics, spatial development and planning, governance and functionality, and financial and administrative factors. A formal investigation were carried out by the MDB in terms of the Municipal Demarcation Act. There are also strong functional linkages between rural communities to the south of Thulamela and east of Makhado local municipalities. Furthermore, the investigation claimed that the new boundary configurations in the Vhembe DM would promote social cohesion by bringing back together the majority of homeland people who were divided along ethnic lines by the apartheid government. On governance and financial and administrative factors, it was found that the reconfiguration of the Vhembe DM would lead to opportunities for the employment of capable and competent management, a spread of revenue base and economies of scale across municipalities in the region (MDB 2015a:43, 47,54, 56).

The process followed in this case demonstrates various participatory mechanisms provided for in the Demarcation Act. How the municipal demarcation process in the CCLM unfolded revealed three different points of view: one view expressed by those who were in favour of the disestablishment of the Mutale LM; one view expressed by those who were in favour of the new municipality, including the government, the MDB and the Malamulele; and one view expressed by those who opposed the establishment of the new municipality by Vuwani residents. Following inputs received from the submissions on the proposal, together with inputs made at public meeting and results from the investigation, the MDB indeed disestablished the Mutale LM. Secondly, the MDB went further and incorporated the two areas of Malamulele and Vuwani to form a new municipality against the wishes of Vuwani residents. Subsequently, the Vuwani Service Delivery and Development Forum, representing community members together with eight chiefs, made an application to the Polokwane High Court for a revision of the decision. The applicants' main complaint alleged a failure by the MDB to consult them with respect to the decision to incorporate the communities of Mashau and Masakona into a new municipality and out of Makhado LM (Makgoba 2016:14).

\section{Reasons for the eruption of Vuwani}

The application to set aside the MDB decision on the establishment of the new municipality was dismissed by the Limpopo High Court in April 2016. In his ruling, Judge Makgoba dismissed the case on the ground that the applicants have not been able to show that the MDB's decision was lacking in rationality (Makgoba 2016:4,31-35). He stated that it could not be correct for the applicants to allege that there was never any consultation, citing the quotation made by Chief Masia, who participated in the MDB's public meeting. The judge also emphasised that the chief talked of the 'submission that we submitted'; therefore, it could not be correct where the applicants alleged that there was never any consultation. From the quoted words of Chief Masia, the judge concluded that almost all the applicants in this case took part in the consultations and deliberations leading to the final demarcation decision. However, the judge further acknowledged in his ruling that it was also clear from the contribution by Chief Masia that the applicants wanted to remain where they were (Makgoba 2016:22,32).

Nevertheless, the Vuwani Service Delivery and Development Forum mobilised residents through protests aimed at raising their concerns and at putting pressure on the government and the MDB to reconsider the demarcation decision. Demonstrations degenerated into damage of public property, especially public schools in 2016 (Rasila \& Musitha 2017:4). 
Residents of Vuwani continue to reject the new municipality. They are appealing to the MDB to reverse its decision, or they would continue with protests until they are incorporated back to the Makhado LM under which they previously fell. Pending a permanent solution to this demarcation crisis, the Limpopo province and the Vhembe DM are providing Vuwani residents with municipal services (Phakgadi 2018:Internet).

Besides the alleged failure by the MDB to consult adequately, the findings from the questionnaire revealed reasons as to why Vuwani erupted. Figure 3 captures participants' views regarding the intentions of the MDB to change municipal boundaries.

When asked what they thought were the reasons behind municipal boundary changes in the area, $10 \%$ of both Malamulele and Vuwani participants replied the changes were politically motivated. Although it could not be established through the questionnaire why participants thought that way, a key interviewee in the Human Sciences Research Council (HSRC) survey questioned the rationale of the boundary redetermination and argued that there was too much political interference in the decision that led to the redetermination of the new municipality (Human Sciences Research Council [HSRC] 2017):

Why add another municipality instead of reducing them? Instead of just expanding another municipality that existed then why add another one called LIM345? We used to watch TV and see them debating in parliament about the merger of the municipalities. But the ruling party seems to have made its mind. (pp. 39-40)

This finding has serious implications for the credibility of the MDB whose responsibility is to define boundaries for effective local government without political interference. As an entity established by the country's constitution to be independent of political machinations, the MDB clearly has to be transparent regarding how it reaches its decisions.

More than one-third (42\%) of the participants in Malamulele believed that changes in municipal boundaries were in the

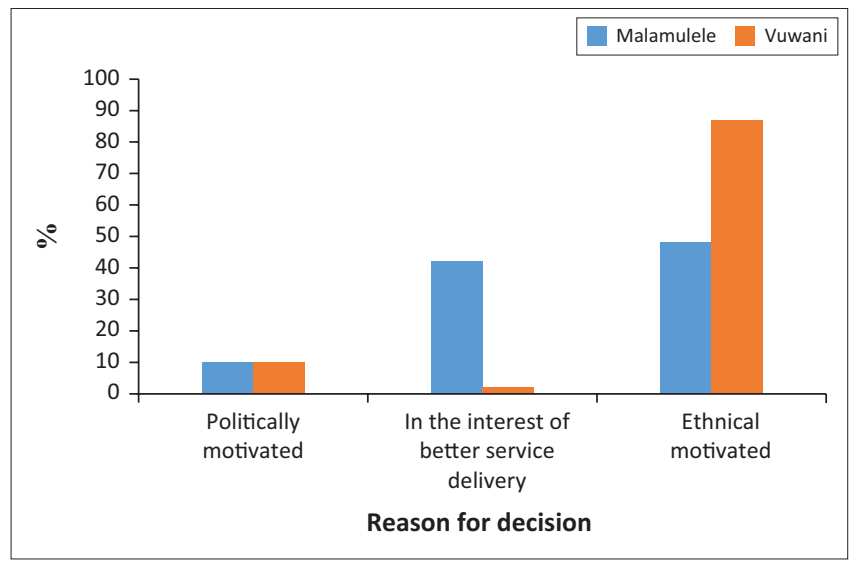

FIGURE 3: Reasons for the Municipal Demarcation Board's decision to change boundaries. interest of better service delivery and as little as $2 \%$ of Vuwani participants thought so. To determine participants' attitudes towards mergers, they were asked if there was a difference in the delivery of municipal services since the merger. As a response, a high proportion of the participants stated that the merger did not make any difference. This response could have much to do with the fact that the merger is recent, and it might thus be too early to tell whether any change has occurred. In some of the municipal boundary protests that ensued in the past in areas such as Khutsong and Matatiele, residents were convinced that service delivery would be severely compromised under a new demarcated area. Others did not want to be incorporated into poorer neighbouring municipalities whose residents would benefit from their resources (Mavungu 2012:60-61; Municipal IQ 2008:1).

For Vuwani participants, ethnic reasons were the most important factor behind boundary redeterminations, and more than $85 \%$ of the participants were convinced regarding this. Essentially, the TshiVenda-speaking participants accused the MDB for manipulating the boundaries to the advantage of the Tsongas. They felt that the government is trying to solve Malamulele demarcation problem at their expense (Nicolson 2017:Internet). The then Head of State, Mr Jacob Zuma, received special blame for imposing undue influence on the MDB by the community of Vuwani. Back in 2015, he had suggested at the funeral service of the late Minister of the Department of Public Service and Administration (DPSA), Mr Collins Chabane, who was from Malamulele, that the area should get its own municipality. Subsequently, Malamulele got its own municipality, expectably named after the former minister (Rasila \& Musitha 2017:4).

Finally, the participants were asked the open-ended question: 'what are your main concerns regarding changes of municipal boundaries?' This question was aimed at establishing some of the reasons for opinions expressed in response to the closeended questions, thereby enriching some of the views expressed in numbers.

A number of concerns were raised about the poor delivery of municipal services in both areas. Almost $80 \%$ of participants from Malamulele were concerned that boundary changes would have a negative effect on access to basic services. On the other hand, 53\% of participants from Vuwani felt the same way. A further $20 \%$ of Vuwani participants did not want to be part of new municipality because they did not ask for it. A good number of Vuwani participants felt that the municipal offices would be too far away. Participants from both areas felt that the new municipality would fuel tribalism and hatred (see Figure 4 ).

Some of the views raised above correlate with some uncertainties raised by the residents of Vuwani in the South African Police Service's survey regarding the new municipality (HSRC 2017):

Fear of the unknown - contesting for positions, fear of being led by Tsonga-speaking people, community service delivery 


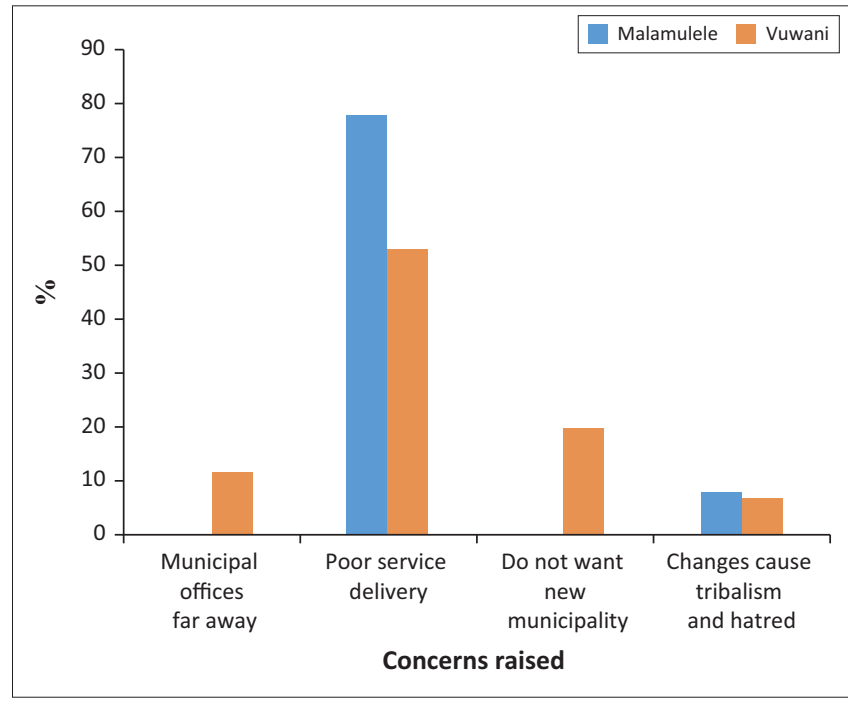

FIGURE 4: Main concerns raised by participants regarding changes of municipal boundaries.

programmes and developments, anticipation of losing business opportunities, minimum job opportunities for Venda people, lack of proper consultation by the MDB, the new Municipality situated in Malamulele, tsonga people will take charge of the new Municipality, no services will be taken to Venda people. (pp. 35-36)

In light of the above discussion, conflicting views are palpable between the authorities on the one hand and society on the other hand. Residents who belong to different ethnic groups confront each other about their inclusion under a local municipality dominated by a certain ethnic group. Such dominance evokes fears of being discriminated against or simply overlooked in relation to services and other developmental opportunities (Hornby 2004:31; Mukwevho 2016:Internet). Whilst it is accepted and indeed imperative that those affected by demarcation decisions have a say, their participation in this case did not seem to have any influence on demarcation decisions. This development raises a number of questions regarding the functioning of local participatory democracy. If the MDB has the final say on demarcation decisions irrespective of the views of those who are affected by the demarcation changes, is there a need for them to participate in the first place? Judge Makgoba dismissed the Vuwani case, but he also acknowledged that the applicants wanted to remain where they were. In this case and other cases referred to in this article, the residents are accusing the MBD for not listening to their views and not considering their objections.

\section{Conclusion}

This article uncovered low levels of public participation in the demarcation process in the CCLM. The majority of participants indicated that they have never taken part in any meetings to talk about municipal boundary changes. Indeed, more people participated in the anti-demarcation protests in Vuwani than in the municipal demarcation meetings. Those who had participated through submissions and attended the public meetings felt that their views were not sufficiently acknowledged. Besides the alleged failure by the MDB to consult adequately, Vuwani residents' objection to demarcation changes seemed to be emanated from other reasons such as fear of unknown, poor service delivery by the new municipality, loss of ethnic dominance and lack of job opportunities. The consultative process that unfolded, which included the circulation of notice to change municipal boundaries, written submissions and public meetings, seemed to fail to advance the theoretical assumptions of democratic principles of transparency. Generally, demarcation protests may be a reflection of a weakness in legal process prescribed by legislation. Residents seem to hold a different view of what public participation in the demarcation process should involve versus what the MDB believes is provided by legislation. In conclusion, this article contends that wherever adequate consultations about proposed demarcation take place, violent objections are unlikely to occur.

\section{The way forward}

There is a need for improvement in the current legal process of determining and redetermining municipal boundaries. Firstly, the publication of the intention to change municipal boundaries through newspapers and other means of communication by the MDB to invite public views on the matter does not seem to be effective. Only 16 submissions in total on the proposed municipality were received by the MDB. Secondly, the participation of traditional leaders in the public hearings on behalf of their communities does not amount to adequate consultation. It is, however, encouraging to note that the current MDB leadership has proposed a number of initiatives, including the development of a public participation framework to address impediments to MDB's approach to public participation. A wide dissemination of the resource booklet entitled Municipal boundary demarcation process: A process map for the determination and redetermination of municipal boundaries (MDB 2017) is urgent in order to empower members of the public to play a meaningful role in these matters. The proposed regionalisation of the MDB offices to ensure that it is closer to the communities is a positive step.

\section{Acknowledgement Competing interests}

The authors have declared that no competing interest exists.

\section{Authors' contributions}

Both authors contributed equally to this work. This article is based on the PhD thesis of M.M. Netswera entitled 'The effects of municipal demarcation on service delivery and social integration in Collins Chabane and JB Marks local municipalities' submitted to the University of South Africa in fulfilment of the degree of Doctor of Public Administration.

\section{Ethical consideration}

Ethical clearance to conduct the study was obtained from the Public Administration and Management Research Ethics 
Review Committee at the University of South Africa (UNISA) on 10 May 2017 (clearance number: PAM/2017/009).

\section{Funding information}

This research received no specific grant from any funding agency in the public, commercial or not-for-profit sectors.

\section{Data availability statement}

Data sharing is applicable to this article as new data were created or analysed in this study, and can be shared upon reasonable request to the authors.

\section{Disclaimer}

The views and opinions expressed in this article are those of the authors and do not necessarily reflect the official policy or position of any affiliated agency of the authors.

\section{References}

Bekink, B., 2006, 'The restructuring (systemization) of local government under the Constitution of the Republic of South Africa, 1996', Unpublished doctoral thesis, University of Pretoria, Pretoria.

Daemane, M.M.M., 2012, 'Prospects and challenges of decentralization for sustainable development through developmental local governance: The experience of smaller nations', Journal of Sustainable Development in Africa 14(8), 199-227.

Department of Co-operative Governance and Traditional Affairs (COGTA), 2015, COGTA annual report for the financial year 2014/15, COGTA, Pretoria.

De Visser, J., 2009, 'Developmental local government in South Africa: Institutional fault lines', Commonwealth Journal of Local Government Issues 2(Jan), 7-25. https://doi.org/10.5130/cjlg.v0i2.1005

Eremenko, M., 2011, Political participation: Model by Verba in the EU and Russia National Research University, Moscow, viewed 20 October 2016, from http:// www.culturaldiplomacy.org/academy/content/pdf/participant-papers/eu/MariaEremenko-Political-participation-Model-by-Verba-in-the-EU-and-Russia.pdf

Finn, J.N., 2008, Building stronger local governments and regions: An action plan for the future of local governance in New Brunswick, Commissioner's Report, Government of New Brunswick, New Brunswick.

Hajnal, Z.L. \& Lewis, P.G., 2003, 'Municipal institutions and voter turnout in local elections', Urban Affairs Review 38(5), 645-668. https://doi. org/10.1177/1078087403038005002

Hornby, D. (ed.), 2004, Shaping South Africa: Reflections on the first term of the Municipal Demarcation Board, South Africa, 1999-2004, Municipal Demarcation Board, Pretoria.

Human Sciences Research Council (HSRC), 2017, 'We didn't ask for a municipality' Unintended consequences of municipal boundary re-determination: Vuwani at a glance, Human Sciences Research Council, Pretoria.

Khumalo, B. \& Ncube, M., 2016, 'Financial and functional viability and sustainability of municipalities: Beyond the demarcation instrument', paper presented at the MDB conference on demarcation and spatial transformation, Financial and Fiscal conference on demarcation and
Commission, Pretoria, 23-24th June.

Mahlangu, L., 2011, Municipal Demarcation Board reviews municipal boundaries for the 2016 local elections, viewed 10 October 2014, from https:// dullahomarinstitute.org.za/multilevel-govt/local-government-bulletin/volume13-issue-4-november-2011/lgb-13-4-november-2011-4-municipal-dermacation13-issue-4-november-2011/lgb-13-4-nove
board-reviews-municipal-boundaries.pdf

Makgoba, J.P., 2016, Vuwani Demarcation Court Case No 1256/2016, High Court of South Africa, Polokwane.
Mapuva, J., 2014, 'Local governance, democratisation and constitutionalism in Zimbabwe', International Journal of Politics and Good Governance 5(5.4), 1-25. http://www.onlineresearchjournals.com/ijopagg/art/162.pdf

Matemba, L., 2000, 'Challenges facing new municipalities', in Southern African Catholic Bishops' Conference Parliamentary Liaison Office Briefing, Paper 36, Cape Town

Mavungu, M.E., 2012, 'Ideological clashes behind provincial boundary disputes in post-apartheid South Africa', South African Geographical Journal 94(1), 60-74. https://doi.org/10.1080/03736245.2012.675734

Michels, A. \& De Graaf, L., 2010, 'Examining citizen participation: Local participatory policy making and democracy', Local Government Studies 36(4), 477-491. https:// doi.org/10.1080/03003930.2010.494101

Mokgosi, D., 2013, Metsimaholo-Ngwathe merger off, viewed 31 January 2017, from http://fstimes.co.za/?p=1307.

Mukwevho, N., 2016, Tribal tension between the Venda and Tsonga groups fuel conflict in Vuwani, viewed 25 June 2016, from http://www.sowetanlive.co.za/news/2016/05/09/ tribal-tension-between-the-venda-and-tsonga-groups-fuel-conflict-in-vuwani.

Municipal Demarcation Board (MDB), 2013, Briefing on demarcation process and challenges to the select committee on co-operative governance and traditional affairs, Parliament, Cape Town.

Municipal Demarcation Board (MDB), 2015a, Vuwani investigation summary report, MDB, Pretoria.

Municipal Demarcation Board (MDB), 2015b, Re-determination of the boundary of the Thulamalela Local Municipality by excluding Malamulele area and determining this area as a separate category $B$ municipality within the Vhembe District Municipality, MDB, Pretoria.

Municipal Demarcation Board (MDB), 2016, Municipal Demarcation Board annual report, 2015/16: Optimising spatial planning through integration, MDB, Pretoria.

Municipal Demarcation Board (MDB), 2017, Municipal Boundary Demarcation process: A process map for the determination and redetermination of municipal boundaries, MDB, Pretoria.

Municipal IQ, 2008, Khutsong back to Gauteng, Briefing \#78, 24 October 2008, Municipal IQ, Johannesburg.

Municipal IQ, 2013, Sasolburg: The importance of communication, Briefing \#415, 22 January 2013, Municipal IQ, Johannesburg.

Mzakwe, S., 2016, 'The legality of the 2015 demarcation proposals by the Minister of Cooperative Governance to the Municipal Demarcation Board', Unpublished master's dissertation, University of the Western Cape.

Napier, J.C., 2007, 'Delimitation of local government ward boundaries in the Tshwane municipal area: The challenge of achieving fair political representation', Politeia 26(2), 179-191.

Nicolson, G., 2017, Vuwani: After the ashes, there's hope, viewed 10 November 2017, from https://www.dailymaverick.co.za/article/2017-05-05-vuwani-after-theashes-theres-hope/\#.WrOq5mpuapo.

Phakgadi, P., 2018, Vuwani residents give govt ultimatum to deal with demarcation concerns, viewed 02 July 2018, from http://ewn.co.za/2018/06/04/vuwaniresidents-give-govt-ultimatum-to-deal-with-demarcation-concerns.

Pillay, P.P., Reddy, S. \& Sayeed, C.M., 2015, 'The South African local government system and the study of public administration', in P.S. Reddy \& M.S. de Vries (eds.), Quo Vadis? Local government and development in South Africa post 1994, Public Administration Today, pp. 328-329, Bruxelles Bruylant, Brussels.

Rasila, B.N. \& Musitha, M.E., 2017, 'Assessing challenges to ineffective communication in government institutions: A case study of Vuwani Area, Limpopo, South Africa', Africa's Public Service Delivery and Performance Review 5(1), 1-10. https://doi.' Africa's Public Service Delivery
org/10.4102/apsdpr.v5i1.177

Reddy, P.S. (ed.), 1999, Local government democratisation and decentralisation: A review of the Southern African Region, Juta, Kenwyn.

Republic of South Africa (RSA), 1996, Constitution of the Republic of South Africa, Government Printers, Pretoria.

Republic of South Africa (RSA), 1998, Local government: Municipal Demarcation Act, Act 27 of 1998, Government Printers, Pretoria.

Scott, M., 2004, Deepening local democracy in the commonwealth, Commonwealth Policy Studies Unit, London.

Sikander, T., 2015, 'A theoretical framework of local government', International Journal of Humanities and Social Science 5(6), 171-176.

Tommasoli, M. (ed.), 2013, Democracy and development: The role of the UN, Discussion Paper, United Nations - International IDEA, New York, NY. 